\title{
GENDERED SPACES: THE IMPACT OF THE CULTURAL ASPECTS ON THE SPATIAL ORGANISATION OF SPACES INSIDE THE HOUSES OF AMMAN DURING THE LAST CENTURY
}

\author{
Bushra ZALLOOM*
}

Received: 01.12.2017; Final Text: 04.01.2019

Keywords: Spatial organisation; spatial segregation; cultural aspects; houses design; privacy.

\footnotetext{
* Department of Architecture, Faculty of Engineering Technology, Zarqa University, Jordan.
}

\section{INTRODUCTION: THE CULTURAL ASPECTS OF THE SPATIAL DESIGN}

The academic literature defines the concept of the house in numerous ways. Some scholars conceive a house as the rich psychological meaning it retains for its occupants (Stafford, 2011; Moore, 2000; Sixsmith, 1986). Other authors, such as Heathcote (2012); Lofgren (2010); and Rybczynski (1987), suggest that a house symbolises a typical social communication that describes the typical style, and represents the social network and social class of its owner. Likewise, Cambo (1991) examined Muslim houses as religious images, abstractions, shelters, and social communities. Accordingly, this research identifies the house as a symbolic place that offers notions of domesticity, comfort, and well-being through domestic intimacy and privacy; it integrates the spatial aspects with the social aspects in design. This interdisciplinary approach gives a comprehensive picture that helps when studying the transformation of the spatial organisation of houses in Amman and its relation to the cultural features.

Exploring the cultural aspects of architecture is essential to comprehend the meaning of space and social relations. The spatial organisation of the interior spaces at the houses in Amman had been affected by various cultural aspects such as religion, tribe traditions, and gender. Islam involves certain religious beliefs that are applied directly to the design of houses in Amman; these beliefs are derived from the Quran (the Muslims Holy book) and Hadith (the record of the words and actions of Prophet Muhammad) (Othman et al., 2014; Mortada, 2011; Campo, 1991). The images of houses expressed in the Quran and Hadith have shaped Muslim ideas about life and faith (Campo, 1991). There is no single interoperation of Islam influences the spatial organisation of spaces inside houses worldwide. Islam has changed considerably over the last century, and began to acquire a completely different definition, one shaped by local 
indigenous cultures than by the original beliefs of the religion (Campo, 1991).

Anthropological theories employ trans-local and transnational approaches to understand the relationship between the cultural aspects and the spatial organisations, and to investigate the intersection of these aspects in complicated and indirect ways (Low and Lawrence, 2010; Rybczynski, 1987). Altman and Chemers (1984) highlighted the importance of the macro-level factors, such as culture and religion in shaping individual's perception of the house. Likewise, Edward Hall (1973) studied the people's use of space as an aspect of culture. He assumed that humans have a distancing mechanism, conceptualised as a bubble surrounding each; this personal space varies in size according to the type of social relationships and situations. Hall (1973) proposed four kinds of personal space ranging from intimate to public and varying by learning and culture (Low, 2003:13 citing Hall, 1973).

Michelle Rosaldo (1974), expanded Hall's assumptions and divided the society, according to culture and gender practices in everyday life, into two zones, public zone for males who are dominant; and private zone for females who are muted and isolated from participation in the social networks. This division operates as a part of larger ideological systems used to restrict women's behaviour within a specific zone (Low and Lawrence, 2010:8 citing Rosaldo, 1974). The concept of public/private zones are used for both, interior designs of the houses and the socially constructed public/private domains. Previous studies such as "The anthropology of space and place: locating culture" -conducted by Low, S., Lawrence, D. in 2010- divided the interior spaces inside the house into public sphere for men and private sphere for women and children; accordingly, this research divides the interior spaces into public/private zones. As a result, women in the Middle Eastern countries embrace gendersegregated spaces that are enforced by the social system to enhance privacy (Othman et al., 2014; Sobh and Belk, 2011). This phenomenon can be recognised when studying the impacts of the cultural aspects on the spatial organisation of houses in Amman.

The spatial dimensions are used to theorise about the differences between males and females and represented asymmetries in power and authority in society (Crossman, 2013; Crespi, 2003). The public/private segregation through the creation of gendered spaces become a required action for controlling the privacy when creating the Muslims' houses (Othman et al., 2015; Sobh and Belk, 2011). Privacy controls the spatial organisation of houses regardless of the religious view; but it can be considered as a primary factor that shapes how Muslims design, perceive and use their house spaces (Omer, 2010).

In Islam, privacy requirements are usually met through precise design by separating the private life from the public relationships (Memarian and Toghr, 2011). Othman et al. (2014) and Mortada (2011) suggested that privacy in traditional Muslim's houses comprises four layers: Privacy between neighbours, privacy between males and females, privacy between family members inside a house, and Individual privacy (Figure 1). Terms like privacy should be anchored with cultural sitting when discussing issues such as gender, space, and cultural dynamics. Privacy is an essential design objective to ensure the separation of female family members within the Muslims' houses (Othman et al., 2014). There are various architectural treatments help in achieving the house privacy, such as the design and the 
Figure 1. Layers of privacy in traditional Muslim's house (Source: Othman et al., 2014, edited by the researcher)

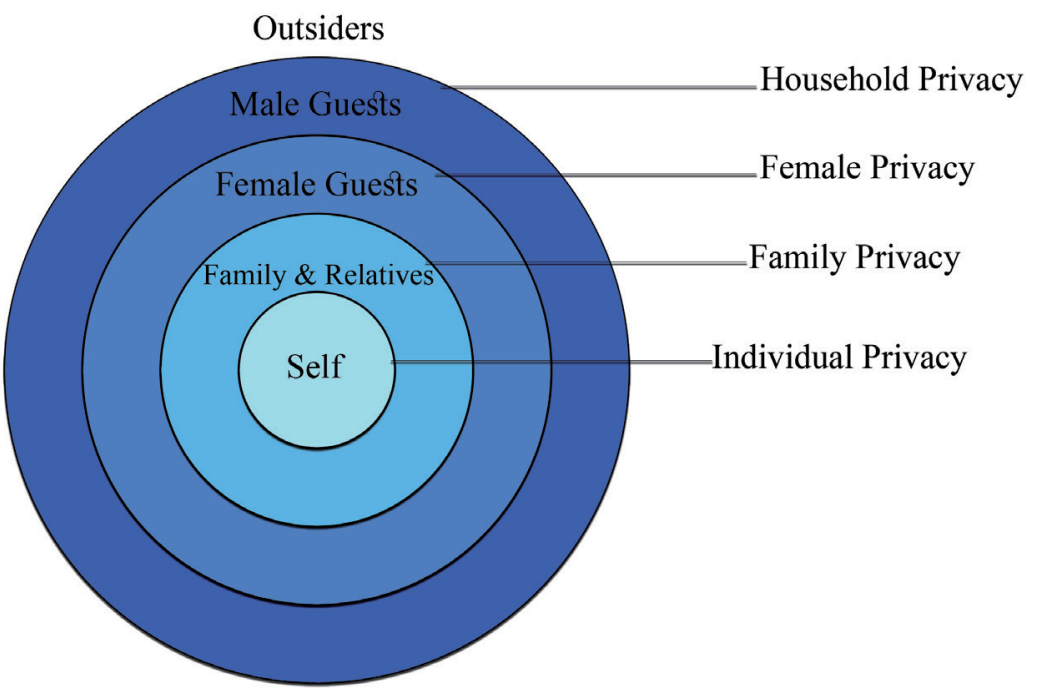

location of the main entrance, the designs and the sizes of windows, the inclusion of courtyards and the creation of gendered spaces by applying the public/private separation (Mortada, 2011; Hakim, 1986). Every house gives its occupants their personal and social requirements regardless of its size, the number of rooms, and the architectural style (Othman et al., 2014).

This research discovers how the cultural aspects affect the spatial organisation of spaces at the houses of Amman during the last century. It aims to explore the users' preference about the spatial organisation of their houses and if they still prefer the spatial segregation to the public zone and the private zone in the contemporary society of Amman. To achieve the research aims, a mixed methods approach that combines between quantitative and qualitative methods are employed to enhance the creditability of the findings. The research outcomes will enhance the architects' understanding about the users' preferences and will help them in designing houses that fulfill the users' needs. To achieve the research aims, the case study of Amman is discussed to comprehend the transformation in the spatial organisation of houses during the last century within various communities. Then, a survey is conducted to investigate the preferred design of houses among youth in Amman during the $21^{\text {st }}$ century, thus, help the architects to imagine the future of houses in this area.

\section{METHODOLOGICAL APPROACH}

The research methods that have been applied in this research are similar to those used in social research. The term "social research" denotes "academic research on topics relating to questions relevant to the social scientific fields" (Bryman 2012:4); such research may be motivated by developments and changes in society. "Academics conduct such research when reflecting on what is going on in modern social life, or when there is a development in a society that provides an interesting point of departure for investigation of a research question" (Bryman 2012:5).

Therefore, to achieve the research aims, a mixed methods approach that combines between quantitative and qualitative methods are employed to enhance the creditability of the findings, and to overcome the minuses of 


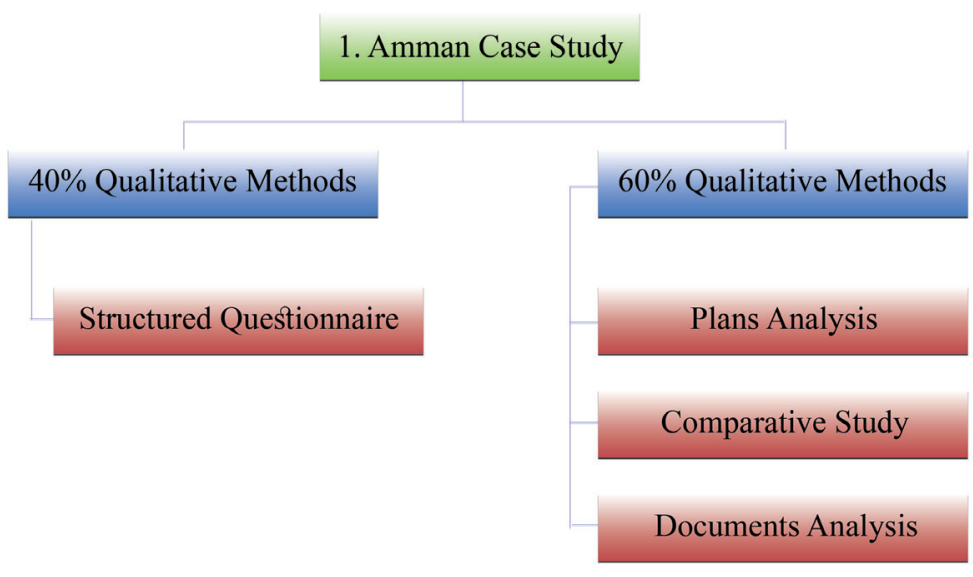

Figure 2. The mixed methods approach (Source: the author)

2. FinalAnalysis and Evaluation

3. Conclusions and Recommendations

using only qualitative or quantitative methods, and because it suits the nature of social study in gathering and analyzing the data and different viewpoints (Bryman 2012). The mixed methods approach is often used -according to Creswell 2003- to ensure that the views and perspectives of a diverse range of participants are represented or when a deeper understanding of a process is sought. Strategies associated with the mixed methods approach in this research lead to data collection and analyses through documents analysis, plans analysis, a comparative study between various types of houses, and structured questionnaire. Accordingly, about $60 \%$ of the implemented methods are qualitative, while only $40 \%$ are quantitative. The research methodology can be embedded within three phases, as shown in (Figure 2).

Phase 1: Amman case study

Qualitative methods

A comparative study has been conducted to analyse the spatial organisation of spaces at different types of houses in Amman to understand the spatial organisation of spaces inside these houses, and to realise the transformation occurred during the last century. The analysis for the house plans is essential for identifying the impact of the cultural aspects on the organisation of spaces by comparing between various types of houses in Jordan. Studying the cultural aspects helps in understanding the reasons behind the differences on the spatial organisation of spaces, and how these spaces have been integrated with or isolated from each other to create the public/private zones.

Quantitative methods

To achieve the research's aims and explore the prefered spatial organisation of rooms among middle-age users, thus, help the architects to design houses that fulfil the family needs and suit the culture of Amman, the researcher conducted an online-survey (1). The participants in the 
Forms" which helps in creating and analysing the Online-survey. This Method will be discussed later in details.

Phase 2: Analysis and evaluation

All the collected data has been further analysed and evaluated to detect the impact of the cultural aspects on the spatial organisation of spaces inside the houses. Statistical analysis, as well as thematic analyses, has been applied to analyse the collected data and present the findings. During this stage, the collected data from various resources should be put into play: spaces, architecture, culture, users, and various relationships.

Phase 3: Conclusions and recommendations

This stage represents the final step which draws up the conclusions and recommendations that take into account the cultural aspects and the spatial aspects of space.

\section{THE CASE STUDY OF AMMAN}

The case study of Amman is discussed to give an actual example of the impact of the cultural aspects on the spatial organisation of rooms inside the houses of Amman during the last century. Since the establishment of Amman in 1921, the multicultural population of the city grouped itself into neighbourhoods according to kinship, tribe, or ethnicity that fit into a range of social structures (Muneef, 1994). The society classified according to the way of living into three types: the urban population or the Urbane, the village population or the Villager, and the nomads or the Bedouin (Zalloom, 2015; Pilder, 2011). Accordingly, the life of people in Amman was a dialogue between Urbane and Villager in their different classes and social background (Zalloom, 2015).

The first type of population is the Villagers, the inhabitants of villages who often work in agriculture, and a few of them work in government jobs (GAM, 2016). In the village house, the plan follows the traditional Islamic pattern of houses where rooms arranged around a courtyard called in Arabic "Hosh" (Figure 3); it has been developed to support women seclusion and enhance the family privacy. The courtyards in traditional houses of Amman allow for adequate distances to avoid direct visibility into the interior spaces of the house; thus increasing the level of privacy. Typically, private spaces cannot be seen from the street, a small entrance hall or passageway is used to separate between the street door and the courtyard (Bekleyen and Dalkilic, 2011). The courtyard is surrounded by the bedrooms, living rooms, kitchen, and bathroom (Othman et al., 2015). The entrance to the house sometimes has a threshold or a simple set of stairs "Atabeh" which placed at the passageway (Iqtait, 2006). The entrance is similar to those found in the traditional Muslim houses where doors located away from the main street and not directly facing the opposite neighbours (Othman et al., 2014; Bekleyen and Dalkilic, 2011; Mortada, 2011). The "Atabeh" in the village house, as described by Muneef (1994), is the first transition point where the male visitors sit and spend their time. Movement from the Atabeh to the family part of the house is through the Hosh to enhance the privacy and prevent a direct look into the private spaces (Iqtait, 2006). Spaces arranged around central courtyards that provide a gradation of privacy, from public spaces for men to private ones reserved for women and children, and the house is always adapted to suit the extended family needs. The cultural settings and beliefs affect the 
Figure 3. The spatial organisation of rooms at the village house in Amman (Source: the author)

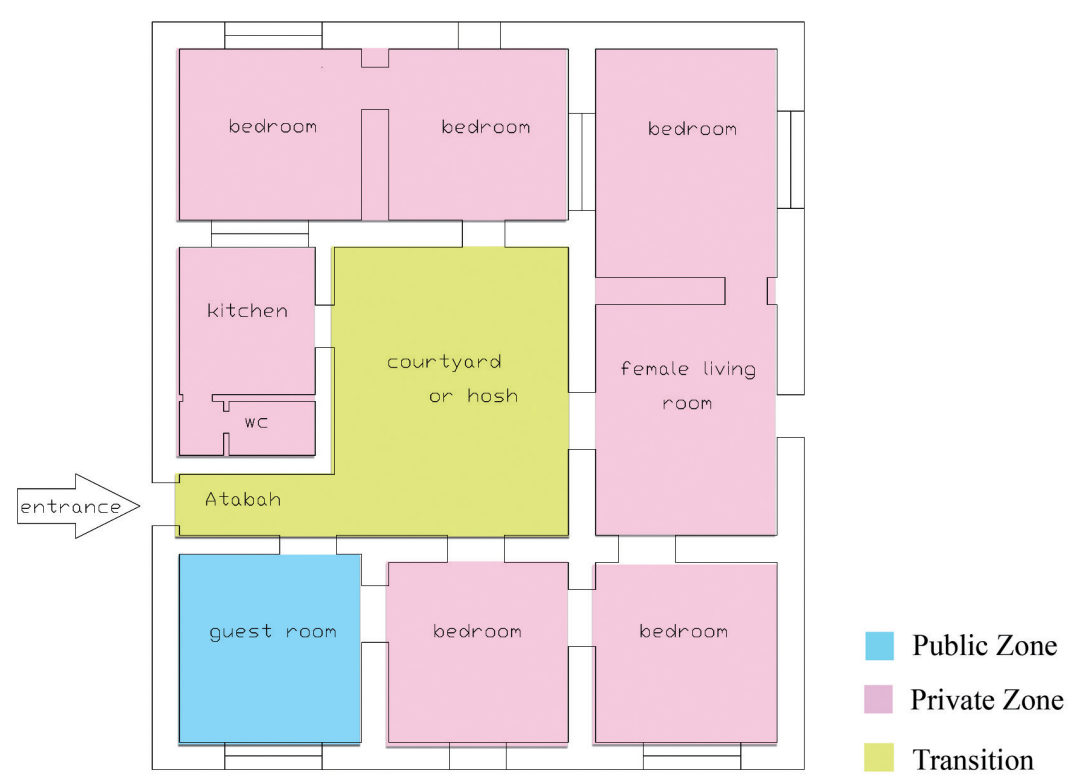

organisation of living spaces in the typical village house in Amman and its surrounding areas.

The second type of population is the urban dwellers who are the inhabitants of cities, and the nature of their lives differs from the Bedouin. The urban dwellers, or the Urbane, live in cement, brick, and stone houses which characterised by geometrical shapes, often in the form of a giant building divided into floors, and floors divided into apartments (Muneef, 1994; GAM, 2016). Urbane in the cities work in government jobs and commerce, so their standard of living is high, and this is reflected in their lifestyle (GAM, 2016). The urbane house is the most frequently recognised gendered spaces in Amman. The interior design for the house is conceptually divided into two zones, public zone for males and their friends, and private zone for females and children (Zalloom, 2015; Gharaibeh, 2011). The structure of the extended family has led to maximising the number of rooms and organising the living spaces in a way that serves all the family members.

Analyzing the interior spaces for different designs of the urbane houses in Amman, from the 1930s to these days, confirms that the interior spaces of the house match the family usage and the privacy concerns (Zalloom, 2015) (Figure 4). The public part of the house includes the guest room which always had a separate entrance, and usually accessible from the main street, while the private part consists of the bedrooms, living room for females' guests and family members, restroom, and kitchen. The kitchen, as described by Zalloom (2015), is located far from the guest room and opened to a minor corridor to enhance privacy; likewise, the bedrooms separated from other spaces by a small corridor. These corridors are transition zones or semi-private areas that connect between the public and the private zones of the house. Further analysis, by the researcher, to the traditional plans of the urbane houses confirms that most houses had a lobby entrance to increase the separation; this lobby had two doors, one leads to the guest room, and the other leads to the private part. Some houses had veranda or balcony instead of the lobby. Male visitors were only allowed to enter the main lobby or were told to remain on the doorstep (Muneef, 1994). So, from 
Figure 4. The spatial organisation of rooms at the urbane houses (Source: the author)

Figure 5. Enhancing the privacy at the residential apartments by providing transition areas (Source: the researcher)
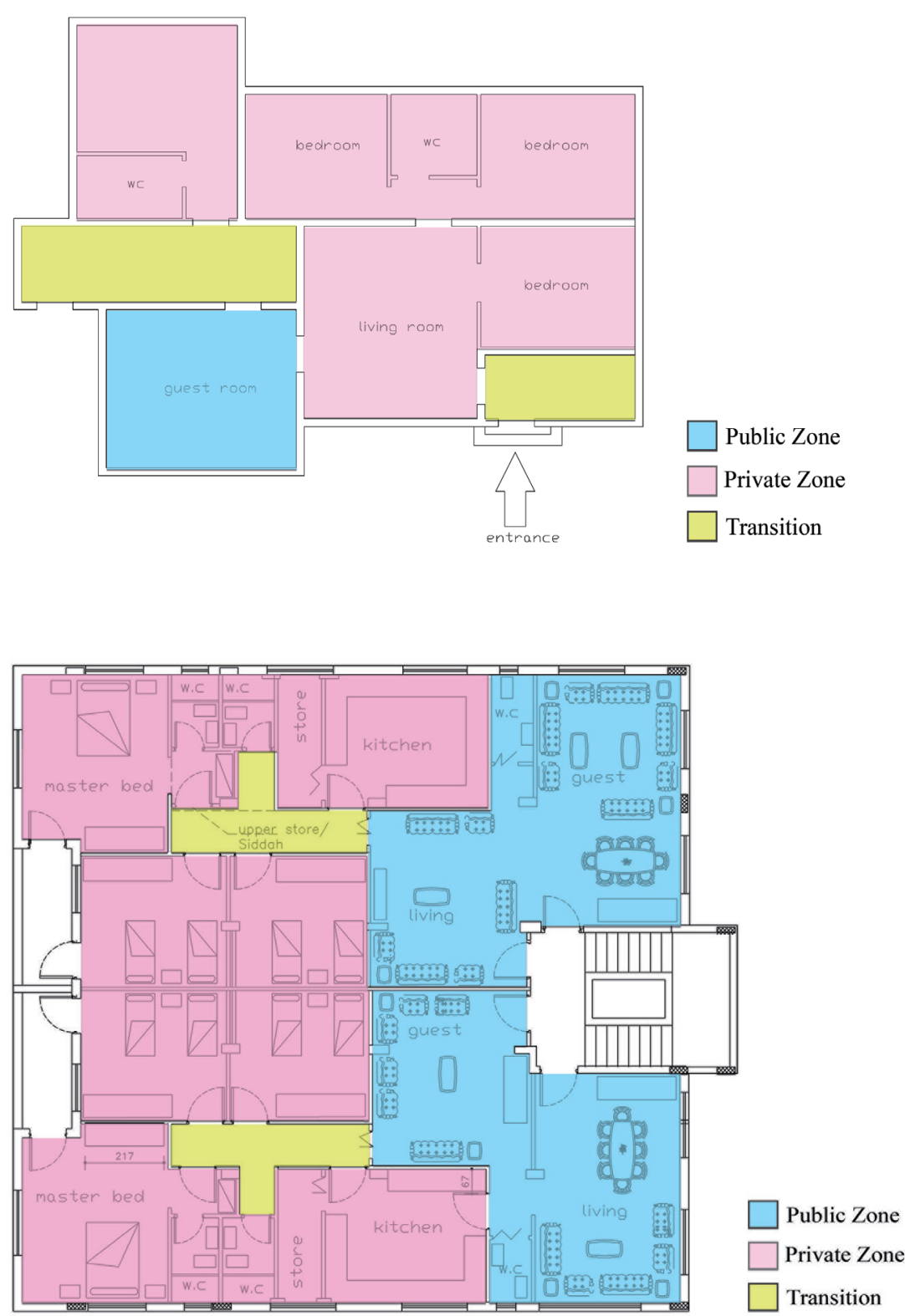

an architectural standpoint, these early houses in Amman emphasised the tribe tradition and followed the rules of Islam, these houses presented the gendered spaces and reflected the social aspects of residents.

Towards the end of the $20^{\text {th }}$ century, the old social structure of the Jordanian family was crumbling, and the centred/single family replaced the extended family which affected the spatial organisation of the house, as well as the number of the bedrooms (Zalloom, 2015; Pilder, 2011). The residential apartments emerged to the city, and many architects who studied architecture abroad at international universities applied the International Style within the local context when they came back to Amman (Pilder, 2011; Potter et al., 2009). Accordingly, the logic of the spatial organisation, as well as the meaning of privacy, started to change. 
Moreover, analysing the urbane houses confirms that they had many spatial boundaries; entrances, corridors, and doors; to separate the public zone from the private zone, servants from family, and children from their parents. The parents' bedroom was located as far away from the main entrance of the house and was a prohibited territory for children (Figure 5).

By the $21^{\text {st }}$ century, globalisation affects the local culture, and the concept of modern living has been developed in Amman. Architects, planners, and social scientists worked together to draw the new society. They believed that the needs and requirements of the modern family differed from the needs and necessities of the traditional one. The design of the contemporary houses in Amman is affected by the European and the American culture. Analyzing the contemporary housing plans shows that the privacy concerns have been decreased during the $21^{\text {st }}$ century, and this affected the spatial organisation of rooms when designing the houses. The American and European styles influence the contemporary designs in Amman. Architects import the modern concepts and apply them when designing the houses, such as the American kitchen, the master bedroom for parents, and the open space plan where the guest room and the living room integrated into one space. They also start designing two bathrooms, one of them for the guests and the other for the family members, besides having the same entrance for guests and the house inhabitants (Figure 6). It seems that the traditional logic of privacy and social control no longer seemed to be functional; and that the private zone no longer considered as a female zone or a resting place.

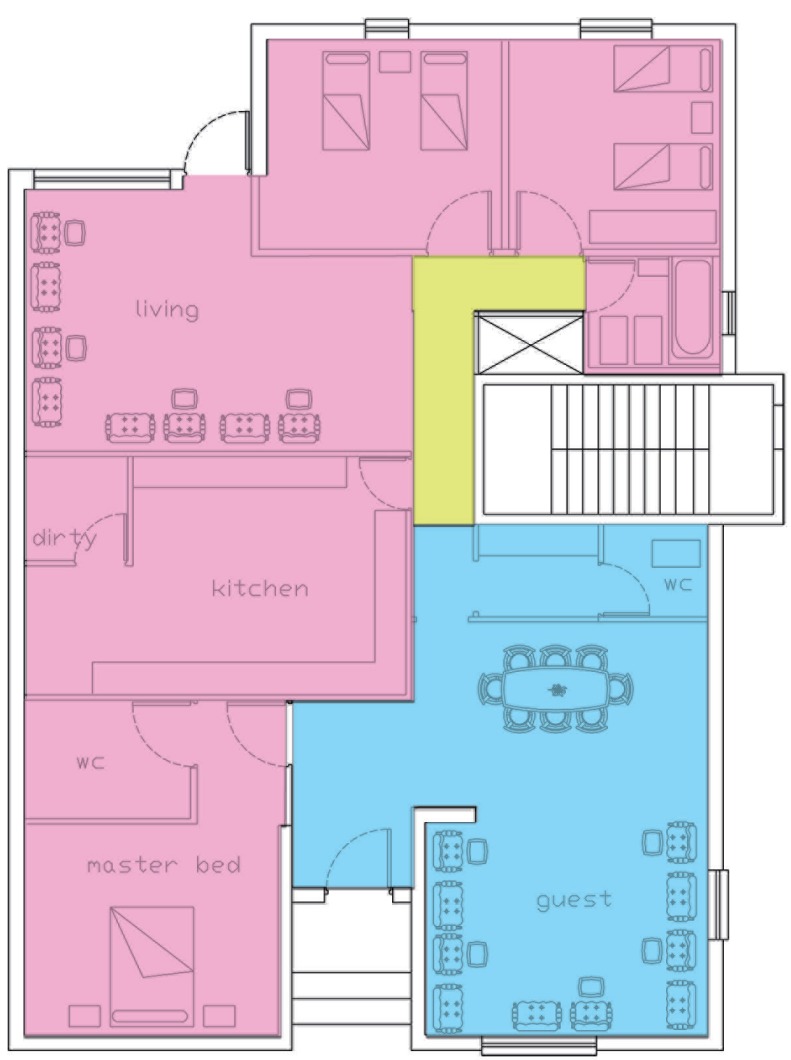

Public Zone Private Zone 
2. Refer to Appendix 1.

3. Refer to Appendix 1.

\section{EXPLORING THE PREFERRED SPATIAL ORGANISATION OF HOUSES IN AMMAN}

\section{The Structured Questionnaire}

To achieve the research's aims and explore the prefered spatial organisation of rooms among middle-age users, thus, help the architects to design houses that fulfil the family needs and suit the culture of Amman, the researcher conducted an online-survey and proposed three house plans with various levels of privacy. The researcher asked 100 persons to choose one plan that suits their needs and justify why they chose it (2). The participants in the survey were selected randomly by uploading the questionnaire on "Google Forms" which helps in creating and analysing the Online-survey. The chosen group includes 55 females and 45 males; all of them are Arabs and Muslims Jordanians from Amman. The participant's ages range from 25 to 50 years old, to ensure variety in needs, roles, and motivations among middle-age users who are looking forward to purchasing a house.

Participants were asked to answer two questions, the first one is a closedend question, while the second is an open-end question. The questionnaire consists of two parts: First part: aims to evaluate the participants' preference for the organisation of spaces inside the house. Three plans were provided, and participants were asked to answer this question "If you are going to buy a house, which one of the following plans (A, B, or C) could be the house you prefer?". Participants were asked to select only one plan that suits their needs and culture. Second part: aims to explore the reasons for selecting this plan by answering this question "Briefly explain why you prefer it?"(3)

\section{Results of the Structured Questionnaire}

The design of the three plans (A, B, and C) based on the theoretical background of the spatial organisation of rooms in the Islam, and derived from analysing some plans and documents for various types of houses that developed in Amman during the last century, in order to understand the spatial organisation of spaces inside these houses. Therefore, the level of privacy and the degree of the spatial segregation to the public/private zone varied in each plan (Figure 7).

The design of plan (A) based on the analyses for the traditional village houses in Amman; therefore, the spatial organization of rooms is almost similar to the village house. It has a clear gradation of privacy, from public zone that include the guest room for men to private ones that include the bedrooms, kitchen, and living room which reserved for women and children. The plan (A) has an entrance hall or a threshold to enhance privacy, and the guest room separated from the bedrooms by a transition area or corridor that plays the role of the Hosh in the village house to prevent a direct look into the private areas.

The design of plan (B) based on the analyses of the contemporary houses of Amman during the $20^{\text {th }}$ century that had been conducted earlier in this research, where the concepts of the American kitchen, the master bedroom for parents. The proposed design is influenced by the American styles that have been spread in Amman, where the privacy level decreases in this plan, as the guest room and the living room integrated into one space, similarly, the kitchen opened to the living room - known in Jordan as the American 


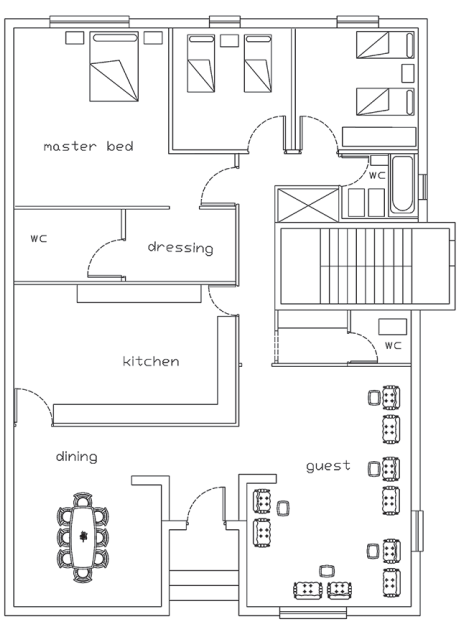

A

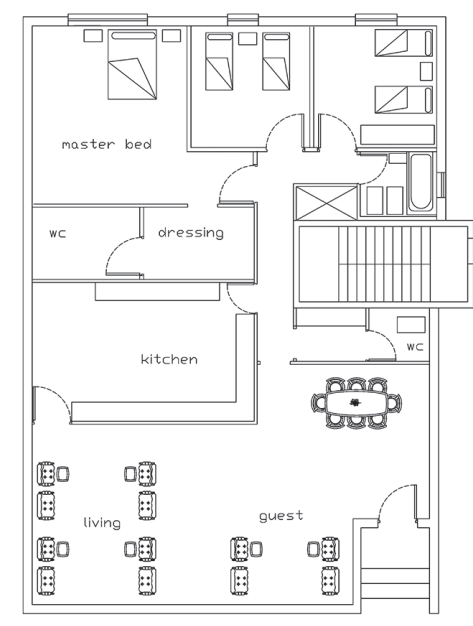

B

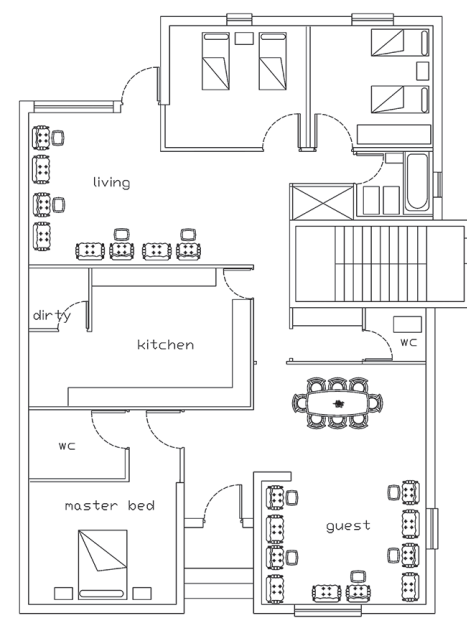

$\mathrm{C}$
Figure 7. The proposed house-plans used in the survey (Source: the researcher). kitchen. Still, the parents' bedroom was located far away from the main entrance and considered as a prohibited territory for children and servants.

The plan (C) intended to integrate the public zone with the private ones. The guest room and the living room form the core of the house; as the plan includes a living room for the female guests, this room has a separate entrance to enhance the user's privacy. While the bedrooms distributed on both sides, the master bedroom located far away from the children bedrooms to enhance the privacy of parents. Likewise, the use of the transition areas and corridors play a vital role in supporting the concept of privacy. The interior spaces of the house match the family usage and the privacy concerns of the $21^{\text {st }}$ century in Amman. Some of the contemporary houses of Amman that started to spread during the last ten years follow this type.

Analyzing the answers of the participants confirms that even in the $21^{\text {st }}$ century, females, as well as males -ages started from 20 years- still prefer to have a high level of privacy and separation of public/private zones. However, the logic of privacy and its profound meaning differs according to their age and gender. Analyzing the questionnaires shows that $50 \%$ of the participants -24 males, and 24 females, most of them are youth (25-35 years old)- preferred plan (A) because it enhances the privacy by using an entrance hall, and a transition area or a corridor, thus eases the circulation of the family members from and to the house, without being seen by guests. Moreover, the privacy increased by separating the private zone that includes the bedrooms from the public zone that includes the guest room for a transition area. On the other hand, $26 \%$ of the target group -7 males, 18 females- selected the plan (B) that offers a big open space compared to other plans; thus can be easily redecorated and furnished. According to them, although this plan does not have the transition area at the entrance area, still the bedrooms are completely separated from the public zone, which offers an acceptable level of privacy to the family members. Some participants who selected plan (B) proposed to build the partitions of the American kitchen to separate the kitchen from the living room, thus, enhancing the privacy of the living room and easing the female circulation 
Figure 8. The participants' preference for various plans (Source: the researcher)

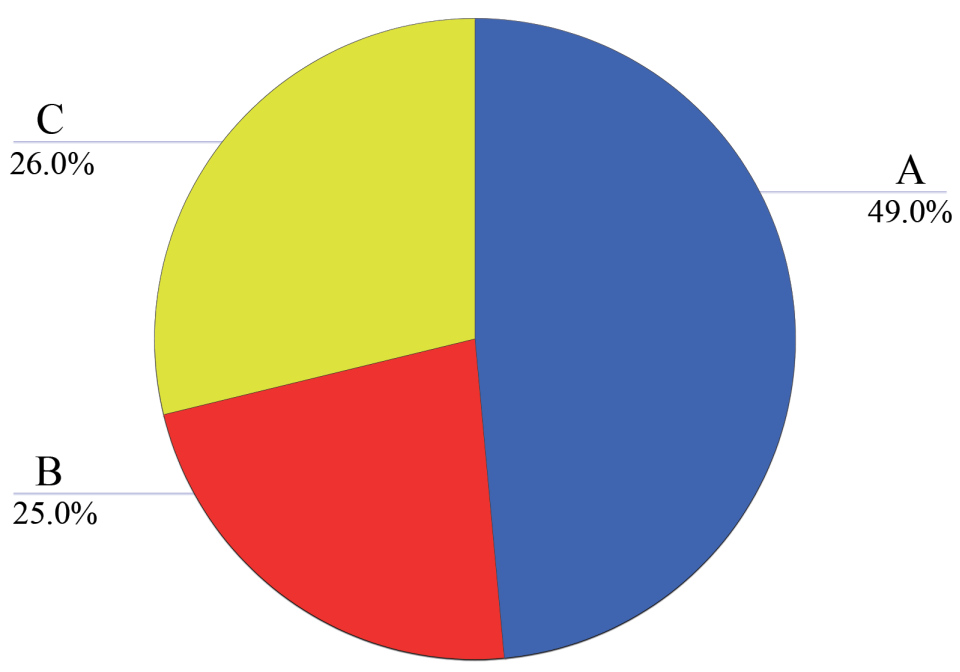

in the house. Only $24 \%$ preferred plan (C) -12 males, and 14 females- most of them are youth (25-35 years old). They believe that this type enhances the parents' privacy because the master bedroom is away from the children room; thus the parents have their space. Similarly, the family living room is far from the guest room and has a separate entrance. According to them, this living room could be used for the females' guests, while the main guest room is for the males' guests. The participants are seeking privacy in their way that is controlled by the cultural aspects and related to traditional thinking of the spatial segregation of public and private zones (Figure 8).

Analyzing the survey outcomes (Figure 9) (Figure 10) confirms that the participants' age played a vital role in selecting the preferred plans. There are 100 participants in the survey, 57 females and 43 males (Table 1). The females preference varies according to their age, in general, 25 of them selected plan (A), 18 of them preferred plan (B), and 14 females selected plan (C). About $42 \%$ of those females, whose ages from 20 to 35 years, preferred plan (A), according to them, plan (A) is preferred because it is organized in two parts, sleeping area and day area which consists of dining room, living room, and kitchen. Moreover, the intermediate space between entrance of the house and other spaces increases the privacy, likewise, the dining room close to the kitchen and the rooms have a good privacy. The second preferred plan for the same group is plan (C). About $33 \%$ of the females -ages from 20 to 35- selected plan (C). For them, it has a more suitable foyer space next to the entrance, the living room is detached from the guest room, the existence of another entrance for female is a privilege, and the master bedroom is separated from the other bed rooms and has a front view. This will increase the privacy for the both males and females. Those who preferred plan (B) -about $24 \%$ of the same age group- explained that the open space area could be used in different ways; living-guestdining area can be joined if needed in one open plan. Moreover, the living room is close to the kitchen while the bedrooms are in a private area that is quiet and kept out of noise. Some participants suggest adding a barrier between the living room and the guest room.

The other group of females -ages from 36 to 45- preferred plan (A) followed by plan (B), then plan (C), 50\% of this age group preferred plan (A) because all the bed rooms beside each other and separated from the guest room, the open space of the guest room and the living room, the kitchen location 
in the middle of the house next to the dining room and close to everyone. $37.5 \%$ of the females ages above 45 preferred plan (B), according to them; it has an open areas, and separated bedrooms in a one zone. The rest preferred plan $(C)$ because it suits their cultural background and provide more spaces for the females especially the separate living room with a special entrance.

The group of females whose age above 45 preferred plan (B), then (A), and $(\mathrm{C})$, as $50 \%$ of this age group preferred plan (B) because it has an open space separated from the bedrooms. $37.5 \%$ of them selected plan (A) because the guest room and the bedrooms are separated from each other. Only $12.5 \%$ preferred plan (C) because it has more privacy and the master bedroom is far away from the children room.

On the other hand, there is 43 males participated in the survey, 24 of them selected plan (A), 12 of them preferred plan (C), and only 7 selected plan (B). In other word, most of the male participants preferred plan (A), as 52\% of them -whose ages from 20 to 35 years- selected this plan because they preferred the separated dining room, and loved the open space that merges the living room with the guest room. About $28 \%$ of males -ages from 20 to 35 years- preferred plan (C) because the guest room and the living room are separated which gives more privacy for the living room and makes it more comfortable. In this plan the Living room is more private and separated from both the guest room and the main entrance which makes it more comfortable especially that the family spends most of the time together in the living room. The living room is also near to the kitchen which is not the case in plan (A). Participants believe that plan (C) gives more privacy as the guest room not close to the living room, and the parents' room not close to the kids' room. Only $20 \%$ of this age group preferred plan (B).

The other group of males, age from 36 to 45 , about $55 \%$ of them preferred plan (A) as they feel it more welcoming. About $22.5 \%$ of this group selected plan (B) because the guest room near the living and the dining room, likewise, the same percentage preferred plan (C) because it suits their culture, as people prefer to separate guests' room from living room. The other reason is the separate entrance for female's guest room. The master bed is also away from guest room which can be considered as important point.

The males' age above 45 years, about $66.6 \%$ of them preferred plan (A), $33.4 \%$ of them preferred plan " $(\mathrm{C})$, and none of them preferred plan $(\mathrm{B})$.

Table 1. The relation between the participants' They mentioned in the questionnaire that plan (A) has more privacy, while preference, gender, and age.

\begin{tabular}{|c|c|c|c|c|c|c|c|}
\hline \multirow{2}{*}{ Age } & \multirow{2}{*}{ Plan } & \multicolumn{3}{|c|}{ Female } & \multicolumn{3}{|c|}{ Male } \\
\hline & & Total No. & No. & Percentage & Total No. & No. & Percentage \\
\hline \multirow{3}{*}{$20-35$} & A & \multirow{3}{*}{33} & 14 & $42 \%$ & \multirow{3}{*}{25} & 13 & $52 \%$ \\
\hline & B & & 8 & $24 \%$ & & 5 & $20 \%$ \\
\hline & C & & 11 & $34 \%$ & & 7 & $28 \%$ \\
\hline \multirow{3}{*}{$36-45$} & A & \multirow{3}{*}{16} & 8 & $50 \%$ & \multirow{3}{*}{9} & 5 & $55 \%$ \\
\hline & B & & 6 & $37.5 \%$ & & 2 & $22.5 \%$ \\
\hline & C & & 2 & $12.5 \%$ & & 2 & $22.5 \%$ \\
\hline \multirow{3}{*}{ Above 45} & $\mathrm{~A}$ & \multirow{3}{*}{8} & 3 & $37.5 \%$ & \multirow{3}{*}{9} & 6 & $66.6 \%$ \\
\hline & B & & 4 & $50 \%$ & & 0 & 0 \\
\hline & C & & 1 & $12.5 \%$ & & 3 & $33.4 \%$ \\
\hline \multicolumn{2}{|c|}{ Total } & \multicolumn{2}{|c|}{57} & $100 \%$ & \multicolumn{2}{|c|}{43} & $100 \%$ \\
\hline
\end{tabular}


Figure 9. The female's preference for the proposed plans
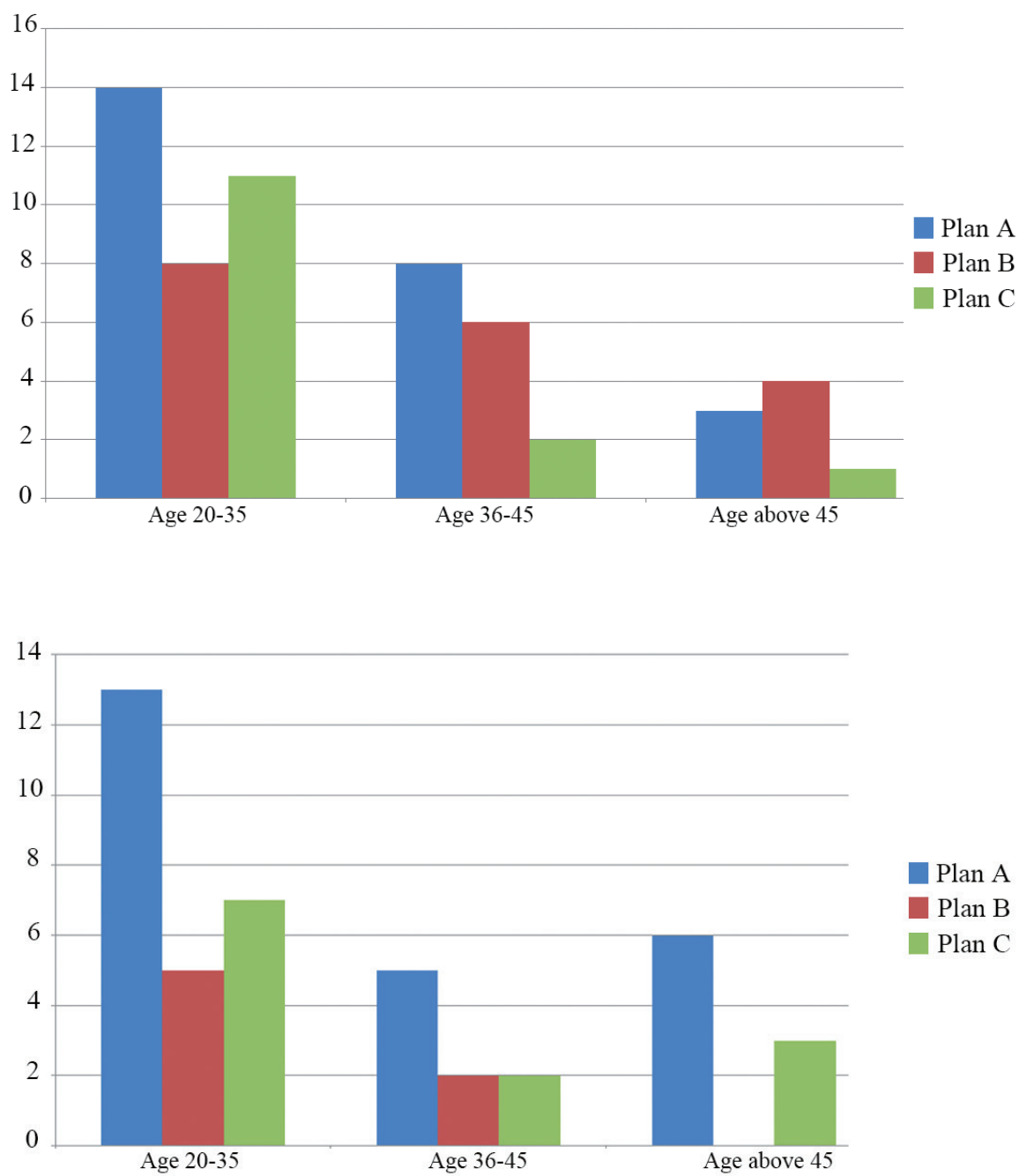

plan (C) suits their culture that prefer having a separate entrance for the guests, plus it is more cozy to have the living room beside the bedrooms.

It is clear that even in the $21^{\text {st }}$ century, the social traditions of privacy and the spatial segregation of spaces to public/private zones are still preferred. However, by the time, the spatial organization of the rooms has been changed to suit the change of the cultural viewpoint for users. The variety in age and gender play a vital role in the survey outcomes. Considering that all the selected group are Arabs and Muslims thus having a similar cultural background. The survey confirms that the most preferred plan among participants -male as well as females- whose age from 20 to 35 varies, is plan (A), followed by (C), and (B). the preference of the second group whose age from 36 to 45 years varies, females preferred plan $(A)$, then, $(B)$, followed by $(C)$, while males mainly preferred plan $(A)$, followed by plan $(B)$ and $(C)$ which have the same percentage. The third group whose age above 45 , females mainly preferred plan (B) followed by (A) and $(C)$, however, none of the males prefer this plan, the preferred plan for males is (A) followed by (C). 


\section{CONCLUSION}

The research discusses the impacts of the cultural aspects on the spatial organisation of spaces inside the houses of Amman. It illustrates how the spatial segregation to public/private zones is a required action to enhance privacy; however, the interpretation of this segregation can differ in methods, levels, and characteristics according to the cultural setting. Furthermore, the research shows that the public/private segregation of spaces at the house has moved away from earlier conceptions of fixed symbolic and territorial associations to consider more sophisticated understandings that anchored with the cultural aspects. The research outcome supports the knowledge of Othman et al. (2014); Crossman (2013); Low and Lawrence (2010); Pellow (2010); and Campo (1991) among others who believe in the impact of the cultural aspects on the spatial arrangement of spaces.

This paper discusses two types of houses in Amman, the villager house and the urbane house. It analyses the spatial arrangement of spaces within each type. The spatial organisation of spaces inside the villager house and the urbane house is affected by the Islam regulation, the tribe tradition, and the cultural context, the social structure, the family structure, and the cultural beliefs. All these factors enhance the family privacy and support the spatial segregation.

The spatial organisation of the spaces inside the houses of Amman offers a high level of privacy; privacy in Islam is met through a precise design that led to creating the spatial segregation of public/private zones and reflected in the form of gendered spaces. Privacy is anchored within the cultural system; this system enforces the public/private segregation when designing the spaces inside the house. However, the logic of privacy and its ways of application have differed by the time. Analyzing the plans of the houses in Amman during the last century shows that the public/private dichotomy was applied for ages and affected the spatial organisation of spaces inside the houses. However, the research suggests that rather than a public/ private dichotomy, it is essential to think about these categories as being both socially constructed and permeable.

The research confirms that assumptions about the need for the spatial segregation at houses might be so deeply embedded in people's minds and linked to their cultural tradition. Even in the $21^{\text {st }}$ century, the religious principles and the social traditions of privacy are still preferred by the users of the space, both men, and women. The transformation in the design of the houses is not accepted by the users, for example, participants in the survey suggest reshaping the open space plan that contains the American kitchen and living room into two separate spaces. All the selected groups in the survey are seeking privacy, but they recognise it from a different perspective. This confirms that while modernity has affected the meanings Muslims attribute to their houses, it has not totally transformed them.

As a result, a sustained attention is required to the relationship between cultural and spatial dimensions of the conceptual scheme, to provide many fruitful opportunities for developing the concept of spatial organisation in a way that suits the gender needs through time. The examination of the spatial and cultural dimensions of the space suggests promising future for further research. The female's attitude towards religious principles and social traditions, and how they may deal with them in contemporary society needs further research to understand the gender needs of modern 


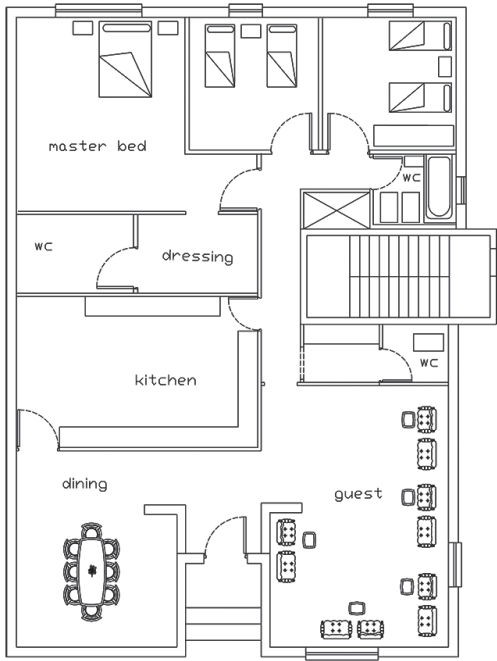

A

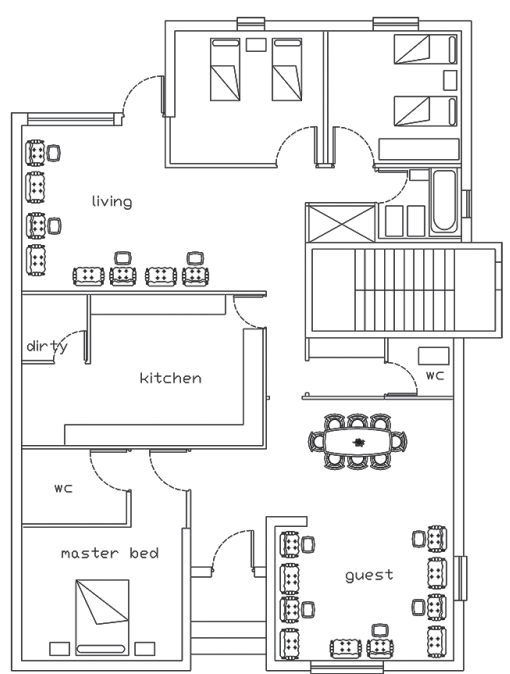

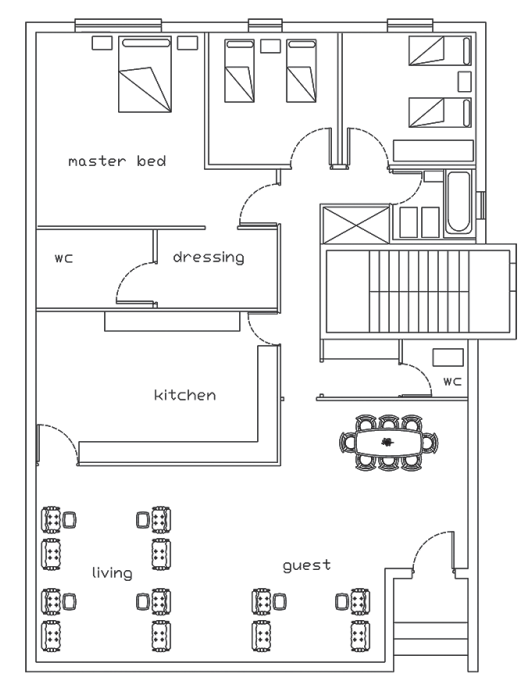

B communities. The people attitude towards religious principles and social traditions, and how they may deal with them in the contemporary society needs further research to understand the needs of users in modern communities that suit their current roles and reflected on the spatial organisation of their houses. Future studies about should consider the changing practice of the Islamic religion and the ever-changing nature of Muslims.

\section{ACKNOWLEDGEMENT}

This research is funded by the Deanship of Research in Zarqa University/Jordan.

\section{APPENDICES}

\section{The Online Survey}

\begin{tabular}{|l|l|l|l|l|l|l|}
\hline $\begin{array}{l}\text { Name } \\
\text { (optional) }\end{array}$ & \multicolumn{2}{|l|}{} & Age & $25-35$ & $36-45$ & $46-50$ \\
\hline Gender & Male & Female & Origin & Arab & Europe & USA \\
\hline Religion & Muslim & Non-Muslim & \multicolumn{3}{|l}{} \\
\hline
\end{tabular}

Q- If you are going to buy a house, which one of the following plans (A, B, or C) would be your favourite place?

Please select only one option then briefly explain why you prefer it?

Answer: -My preferred plan is: 


\section{REFERENCES}

ARDENER, SH., (1993) Women and Space: Ground Rules and Social Maps, Berg Publishers.

ALTMAN, I., CHEMERS, M. (1984) Culture and Environment. Cambridge University Press, Cambridge.

BEKLEYEN, A., DALKILIC, N. (2011) The Influence of Climate and Privacy on Indigenous Courtyard Houses in Diyarbakır, Turkey Scientific Research and Essays 6(4)908-922.

BRYMAN, A. (2012) Social research methods' Oxford, Oxford University Press.

CAMPO, J. (1991) The Other Sides of Paradise: Explorations into the Religious Meanings of Domestic Space in Islam (Studies in Comparative Religion), South Carolina, University of South Carolina Press.

CRESPI, I. (2003) Gender Socialization Within the Family: A Study on Adolescents and Their Parents in Great Britain, Catholic University of Milan.

CRESWELL, J. (2003) Research Design: Qualitative, Quantitative, and Mixed Methods Approaches, London, SAGE Publications Inc.

CROSSMAN, A. (2013) Sociology of Gender: Studying The Relationship Between Gender And Society, [http://sociology.about.com/od/Disciplines/a/ Sociology-Of-Gender.htm], Accessed on 30.6.2018.

GREATER AMMAN MUNICIPALITY (2016), Amman story. [www. ammancity100.jo/en/content/story-ammanl, Accessed on 15.5.2018GHARAIBEH, K. (2011) The Historical and Architectural Development of Amman, Damascus University Magazine. 3(27) 471502.

HAKIM, B. (1986) Arabic-Islamic Cities: Building and Planning Principles, KPI, London.

HALL, E. (1973) The Silent Language, New York, Anchor Books.

HEATHCOTE, E. (2012) The Meaning of House, Frances Lincoln Limited, London.

IQTAIT, I. (2006) An Architectural Survey of Raboud (South of Hebron). [http:// www.webjournal.unior.it/Dati/17/42/Article\%20Ibrahim.pdf $]_{\llcorner}$ Accessed on 30.7.2018

LOFGREN, O. (2010) The Sweetness of House: Class, Culture and Family Life in Sweden, The Anthropology of Space and Place: Locating Culture, eds. Low S. and LAWRENCE-ZUNIGA, D., Blackwell Publishing; 142-159.

LOW, S. (2003) Embodied Spaces: Anthropological Theories of Body, Space, and Culture, SAGE.

LOW, S., LAWRENCE, D. (2010) The Anthropology of Space and Place: Locating Culture, Blackwell Publishing.

MEMARIAN, G., TOGHR, S., Ranjbar-Kermani, A. (2011) Privacy of House in Islamic Culture: A Comparative Study of Pattern of Privacy in Houses in Kerman. International Journal of Architecture, Engineering, and Urban Planning, 21(2) 69-77. 
MOORE, J. (2000) Placing House in Context, Journal of Environmental Psychology, 20(3) 207-216. [http://dx.doi.org/10.1006/jevp.2000.0178],_ Accessed on 30.7.2018.

MORTADA, H. (2011) Traditional Islamic Principles of Built Environment, Routledge Curzon, New York.

MUNEEF, A. (1994) City story: Amman During Forties, Dar al Faris publishing.

MUSEUM: Bibs, Babs, Bobs of Amman (2017) The Story of A Small Expat Family Living in Amman. [http://expatfamilyinamman.blogspot. co.uk/2010/04/couple-of-museums-in-amman.html], Accessed on 22.9.2018.

OMER, S. (2010) Islam and Housing, Kuala Lumpur, Malaysia.

OTHMAN, Z., AIRD, R., BUYS, L. (2015) Privacy, Modesty, Hospitality, and the Design of Muslim Houses: A Literature Review, Frontiers of Architectural Research (4) 12-23.

OTHMAN, Z., AIRD, R., BUYS, L. (2014) Observing Privacy, Modesty and Hospitality in the House Zone: Three Case Studies of Muslim Houses in Brisbane, Australia, International Journal of Architecture Research, 8(3) 266-283.

PELLOW, D. (2010) The Architecture of Female Seclusion in West Africa,, The Anthropology of Space and Place: Locating Culture, eds. LOW, S. and LAWRENCE, D., Blackwell Publishing, 164-169.

PILDER, A. (2011) Urbanization and Identity: The Building of Amman in the Twentieth Century, unpublished Master Thesis, Miami University.

POPULATION: World Population Review (2017) Population of Cities in Jordan. [http://worldpopulationreview.com/countries/jordanpopulation/cities/],Accessed on 22.9.2018.

POTTER, R. et al. (2009) Ever-growing Amman, Jordan: Urban Expansion, Social Polarization and Contemporary Urban Planning Issues, Habitat International, (33) 81-92.

RASHEED, A. (2002) Scenes of Social Life in Amman from 1948 to 1976, GAM.

ROSALDO, M., LAMPHERE, L. (1974), Woman, Culture, and Society, Stanford University Press.

RYBCZYNSKI, W. (1987) House: A Short History of an Idea, Penguin Books, New York.

SIXSMITH, J. (1986) The Meaning of House: An Exploratory Study of Environmental Experience, Journal of Environmental Psychology, 6(4)281-298. [http://dx.doi.org/10.1016/s0272-4944(86)80002-0], Accessed on 12.5.2018.

SOBH, R., Belk, R. (2011) Zones of Privacy and Hospitality in Arab Gulf Houses. Journal of Islam, 2(2) 125-137.

STAFFORD, A. (2011) The Psychological Significance of House, unpublished Ph.D. Thesis, The Wright Institute, Ann Arbor.

ZALLOOM, B. (2015), The Social Sustainability of Urban Landscape, unpublished Ph.D. Thesis, Birmingham City University. 
Alınd1: 01.12.2017; Son Metin: 04.01.2019 Anahtar Sözcükler: Mekansal organizasyon; mekansal ayrışma; kültürel unsurlar; ev tasarımı; mahremiyet.

\section{TOPLUMSAL CINSIYYET MEKANLARI: KÜLTÜREL UNSURLARIN AMMAN EVLERININ MEKÂNSAL ORGANIZASYONUNA SON YÜZYILDAKİ ETKİSI}

$\mathrm{Bu}$ araştırma, evlerin iç mekân düzenlemelerinde, kültürel ve mekânsal unsurlar arasındaki ilişkiyi araştırmakta ve kültürel unsurların Amman evlerinin iç mekân planlaması ile ilgili geniş bir yelpazedeki konuyu geçtiğimiz yüz yıl boyunca nasıl etkilediğini tartışmaktadır. Çalışma, mahremiyet ihtiyacının iç mekân tasarımında kamusal alan/ özel alan ayrımına izin veren hassas bir tasarımla nasıl karşılandığını göstermektedir. Evlerdeki mekânsal organizasyonu araştırmak ve kültürel özellikleri anlamak önemlidir. B,u mekânların geleceğini tahayyül edebilmeye imkân sağlar. Benzer şekilde, kültürel müzakereleri araştırmak mimarların mimari uygulamalardaki yorumlamaları hakkındaki anlayışını geliştirebilir ve bu uygulamaların kullanıcı ihtiyacına göre geliştirilmesine yardımcı olabilir.

Makalede kent ve köy evi olmak üzere Amman'daki iki tip ev incelenmektedir. Bu türdeki mekanların mekansal düzenlemesi yanı sıra İslami düzenlemeleri, kabile geleneklerini ve kültürel bağlamı yansıtan planları mimari açıdan incelenmektedir. Kullanıcıların evlerinin mekânsal organizasyonu hakkındaki tercihlerini ve hala Amman'ın çağdaş toplumunda kamusal-özel mekânsal ayrımını tercih edip etmediklerini rtaya çıkarmayı amaçlamaktadır. Bu amaca yönelik olarak, nitel ve nicel yöntemleri bir araya getiren karma bir yöntem, bulguların güvenilirliğini arttırmak için kullanılmıştır. Araştırma bulgularının mimari uygulamaları, tasarım yaklaşımlarını ve evlerdeki yaşam kalitesini etkileyecek nitelikte olduğu düşünülmektedir.

\section{GENDERED SPACES: THE IMPACT OF THE CULTURAL ASPECTS ON THE SPATIAL ORGANISATION OF SPACES INSIDE THE HOUSES OF AMMAN DURING THE LAST CENTURY}

This research explores the relationship between the cultural aspects and the spatial aspects when organising the spaces inside the houses, and discusses how the cultural aspects affect a broad range of matters associated with the arrangement of the spaces inside the houses of Amman, the capital of Jordan, during the last century. It shows how privacy requirements are met through precise design that led to the public/private segregation when designing the interior spaces. Studying the spatial organisation at the houses and understanding the cultural features is essential, it allows the researchers to imagine the future of these spaces. Likewise, exploring the cultural negotiations could enhance the architect's understanding of their interpretations in architectural practices, and help them to develop these practices to suit the users' needs.

The paper discusses two types of houses in Amman, the urbane house and the village house. It studies the spatial arrangement of spaces within these types and the architectural treatments of the plans that reflect the Islam regulations, the tribe traditions, and the cultural context. It aims to explore the users' preference about the spatial organisation of their houses and if they still prefer the spatial segregation to the public zone and the private zone in the contemporary society of Amman. To achieve the research aims, a mixed methods approach that combines quantitative and qualitative methods are employed to enhance the creditability of the findings. The research findings shall impact on the professional practice, the design approach, and the quality of life within the houses. 
BUSHRA ZALLOOM; B.Arch, M.Sc., PhD.

Received her B.Arch in Architectural Engineering in 1998, and MSc. in Landscape architecture in 2011 from the Faculty of Architecture at the University of Jordan. Earned her PhD. degree in the Social sustainability of urban landscape from the Birmingham City University in United Kingdom (2015). Major research interests include urban design, urban landscape, landscape architecture, and sustainabilty. bzalloom@zu.edu.jo 
